Journal of Management and Economic Studies

2019, 1(1): 66-78 DOI: 10.26677/TR1010.2019.61

Journal Homepage: https://www.jomaes.org

\title{
Free Trade Zones: A Strategic Evaluation of Nigeria Success (Failure) Story
}

\author{
Ifeoma Betty Ezike \\ Monetary Policy Department, Central Bank of Nigeria
}

\section{Angela Ifeanyi Ukemenam}

Department of Banking and Finance, University of Nigeria, Enugu Campus, angela.ukemenam@gmail.com

\section{Ikenna Franklin Chijioke}

Ikenna Frankline Chijioke, Ph.D Niger Delta Development Commission, Owerri, Imo State, officeikedivine@yahoo.com

\begin{abstract}
This paper represents a strategic evaluation of the performance of free trade zones in Nigeria. The paper used Krugman (1991) and Bergsten (1991) analysis on free trade zone to lay the theoretical argument for and against free trade zone. The study also reviewed Nigeria's free trade regulatory framework and environment. The strategic evaluation of the performance of free trade zones in Nigeria, using anecdotal evidence revealed that the free trade zones have not achieved the objectives for which they were established. Based on the findings, the paper made far-reaching recommendations on strategic to rejig the free trade zones, in order to ensure that they function optimally, in line with the developmental objective of Nigeria.
\end{abstract}

Keywords: Free Trade Zones, Strategic Evaluation, Nigeria

\section{Introduction}

According to Miyagiwa (1986), the origin of free-trade zones (FTZs) dates back at least to the days of Alexander the Great. After laying siege to the Phoenician Island fortress of Tyre, Alexander granted protection to the merchants there and as a result, Tyre prospered by attracting trade from the rest of the world. While it may seem as if FTZs have an extensive history, it is only within the last decade that they have begun to play a prominent role in international trade. Today some 70 countries around the world operate a total of about 400 FTZs, mostly in less developed countries (LDCs).

The oldest known free port established expressly to promote trade was the Roman Free Port on the Aegian Island of Delos, which acted as a custom free centre promoting trade between 
Egypt, Greece, Syria, North Africa, Asia and Rome. This is followed by Geneoa, Venice and Gibaraltar. The true forerunner of the FTZ was the free port of Hamburg, established in 1888. It was granted special privilege of manufacturing, on the condition that it would stay exportoriented.

The world's first Free Trade Zone was established in Shannon, Ireland (Shannon Free Zone). This was an attempt by the Irish Government to promote employment within a rural area, make use of a small regional airport and generate revenue for the Irish economy. It was hugely successful, and is still in operation today. The number of worldwide free-trade zones proliferated in the late 20th century. Free trade zones in Latin America date back to the early decades of the 20th century. The first free trade regulations in this region were enacted in Argentina and Uruguay in the 1920s. The Latin American Free Trade Association (LAFTA) was created in the 1960 Treaty of Montevideo by Argentina, Brazil, Chile, Mexico, Paraguay, Peru, and Uruguay. However, the rapid development of free trade zones across the region dates from the late 1960s and the early 1970s. Latin American Integration Association is a Latin American trade integration association, based in Montevideo.

In the United States free-trade zones were first authorized in 1934 through the US (Foreign Trade Zones Act of 1934). Corporations setting up in a zone may be given tax breaks as an incentive. Usually, these zones are set up in underdeveloped parts of the host country; the rationale is that the zones will attract employers and thus reduce poverty and unemployment, and stimulate the area's economy. These zones are often used by multinational corporations to set up factories to produce goods (such as clothing or shoes).

\section{Conceptual Issues}

Any area known as FTZ is but a latter development of the age-old concept of free port. Other well-known synonyms of FTZ are Investment Promotion Zone (IPZ); and Export Promotion Process Zone (EPZ). However, too often, FTZ are commonly mistaken for Free Trade Area (FTA). An FTA is nothing but an area formed by reciprocal multilateral agreements limiting or eliminating custom duties on trade among its members. Examples are European Free Trade Area and Latin American Free Trade Area. There is also a misconception between FTZs and Free Port (FP). Though, FTZs are closer to ports, it is not the same as FPs. A FP would merely function as a Trans-shipment Centre or a bonded warehouse facilitating international trade.

A free trade zone (FTZ) is a specific class of special economic zone. They are a geographic area where goods may be landed, handled, manufactured or reconfigured, and re-exported without the intervention of the customs authorities. Only when the goods are moved to consumers within the country in which the zone is located do they become subject to the prevailing customs duties. Free-trade zones are organized around major seaports, international airports, and national frontiers - areas with many geographic advantages for trade.

\subsection{Difference with Export Process Zone}

An Export processing zone (EPZ) is a specific type of FTZ, set up generally in developing countries by their governments to promote industrial and commercial exports. Most FTZs located in developing countries: Brazil, Colombia, India, Indonesia, El Salvador, China, the Philippines, Malaysia, Bangladesh, Pakistan, Mexico, Costa Rica, Honduras, Guatemala, Kenya, Sri Lanka, Mauritius and Madagascar have EPZ programs. In 1997, 93 countries had set up export processing zones employing 22.5 million people, and five years later, in 2003, EPZs in 116 countries employed 43 million people. China has specific rules differentiating an EPZ from a FTZ. For example, 70\% of goods in EPZs must be exported, but there is no such quota for FTZs. 


\subsection{Features of FTZs}

Though the actual policies governing FTZs differ in detail among countries, there exists a set of common characteristics which they share. First, the commodities produced in FTZs are exportoriented. In fact most of them are directly exported without ever entering the domestic markets. For example, the Malaysian government requires that ad least 80 percent of zone manufactured goods be exported, whereas in Taiwan the export requirement ratio is 100 percent.

Second, the exports from FTZs are typically non-traditional manufactured goods, e.g. the Santa Cruz Electronics Export Processing Zone in India is specialized in electronic products. Third, the firms located inside FTZs receive a variety of incentives from the government not accorded to the firms outside. These incentives are direct and indirect export subsidies including tariff rebates on intermediate goods, reduced taxes, absence of labor union activity, and freedom for foreign firms to remit profits overseas.

Fourth, in order to increase employment, LDC governments generally prefer the zone based firms to be relatively labor-intensive. For instance, no firms are permitted to operate in the Kaohsiung Export Processing Zone of Taiwan unless their labor costs exceed 20 percent of the total costs. It is a region where a group of countries has agreed to reduce or eliminate trade barriers. Free trade zones can also be defined as labor-intensive manufacturing centers that involve the import of raw materials or components and the export of factory products.

\section{The Great Debate on Factors that Influenced FTZs}

There are at least two reasons for the popularity of FTZs in developing countries. The first is that by exempting foreign firms from the tariffs on imported intermediate goods and raw materials which domestic firms must pay, FTZs can serve as an inducement to attract much needed foreign capital to stimulate employment and growth. The second reason for utilizing FTZs is political. FTZs represent only a partial reform of the protectionist policies prevalent in the $50 \mathrm{~s}$ and $60 \mathrm{~s}$ and hence are politically more acceptable to the policymakers of developing countries than a complete liberalization of the policies, since that is likely to elicit much stronger objections from all vested interests. This section focuses on the latter, while the benefits will be discussed in section (3.1).

General Agreement on Tariffs and Trade (GATT) which was signed by in 1947 by 23 nations in Geneva, with the purpose of substantially reducing tariffs and other barriers and the elimination of preferences, on a reciprocal and mutually advantageous basis, was a major move to liberalise global trade. With the establishment of World Trade Organisation by 123 nations under the Uruguay Round Agreement in April 1994, the GATT was jettisoned, though; WTO still contains the essential ingredients of GATT. There is a current debate on the desirability of FTZs compare to free global trade. What has emerged from the debate could be summarized as follows:

\section{Three Central Strands of Pual Krugman (1991) Analysis of FTZs}

- That they are considerably better in practice than in theory;

- That this is the practice when they are viewed as alternatives to multilateral trade liberalization because half a loaf is better than none;

- Which is how they should be viewed because of the demise of the GATT and the poor prospects of the Uruguay Round (UR) 


\section{Bergsten (1991) views are fundamentally different from Krugman}

- That FTZs are considerably less desirable than Krugman suggests, especially in practice;

- That this is particularly true if they are seen as alternatives to an effective global trading system;

- $\quad$ But that, fortunately, they need not be seen as alternatives because the UR is quite likely to succeed, thereby restoring the credibility and central role of the GATT, as complements to such a global system, is acceptable and even desirable.

\subsection{Advantages and Disadvantages of FTZs Using Global Trade Theorem}

In their views, free trade zone are not necessarily a good thing economically, because they may leads to trade diversion rather than trade creation. In the highly imperfect politics of international trade, regional free trade zones could upset the balance of forces that allowed the creation of a fairly liberal world trading system. However, it is thriving because of the inability of world leaders to liberalise trade globally.

In Krugman's view, FTZs are bad in theory but good in practice. He indicated that free zones are bad because they potentially divert trade from low cost to high cost suppliers. Trade diversion occurs when a member of a free trade zone imports a good or service from a country inside its zone rather than from a lower cost, non-member country. He also indicated FTZs can harm non-member countries, not only by reducing the demand for the exports, but also by reducing the relative prices of their exported products. The decline in prices in non-member countries relative to prices in member countries - a "beggar-thy-neigbour" effect - reduces nonmember country welfare. Additionally, he held that trade zones potentially impede trade by promoting trade warfare.

Krugman however argued that, in practice, free trade zones are likely to help more than hurt the world economy, largely because they increase the size of markets. Larger markets lead to greater productive efficiency and competiveness. Thus, trade zone are likely to create more trade than they divert. Moreover, he argued that trade zone seems to be forming along 'natural geographic boundaries. Countries naturally tend to trade more with their neighbours than with distant countries because of transporting goods and services and communicating over long distance is costly. As a result, free trade zones among neigbouring countries may, in practice, be good for the world.

The gains from freeing trade within regional zones will be larger and the costs of reducing trade across zones smaller than implied by moving to zones that are not based on natural geographic boundaries. Finally, Krugman argued that moving toward global trade liberalization through the GATT process is hopelessly stalled, making free trade zone the only viable alternative. Among the reasons Krugman cited for the demise of the GATT are decline of United States as the principal world economic power, the increasing importance of such non-tariff barriers as domestic regulation and investment policies, and the growth of new players in the world economy, such as the Japanese, who arguably play by a different set of rules.

\subsection{Advantages and Disadvantages of FTZ Using Welfare Effect}

Despite the recent proliferation of FTZs little effort has been made to apply trade theory to this phenomenon. The only major theoretical work is by Hamada (1974) and the extensions by Rodriguez (1976) and Hamilton and Svensson (1982). 


\subsubsection{Hamada (1974) Model}

Hamada major proposition is that an exogenous increase in foreign investment within the zone decreases national welfare if the importable sector is relatively capital-intensive. The intuition is that an increase in foreign capital in the FTZs attracts labour from the domestic zone. The Rybczynski Theorem implies that if the importable good is relatively capital-intensive, then its output will increase, worsening the distortion due to the tariff and lowering national welfare.

\subsubsection{Hamilton and Svensson (1982)}

They offer an important critique of the Hamada model. They point out that Hamada's two propositions depend crucially on his implicit assumption that good 1 is not produced in the FTZ. In Hamada's setup, however, there is nothing to preclude production of good 1 in the FTZ since firms in industry 1 are indifferent between producing in the zone and producing in the domestic market. If good 1 is indeed produced in the FTZ, then, as Hamilton and Svensson argue, Hamada's propositions do not hold.

\subsubsection{Miyagiwa (1986)}

Miyagiwa feels that Hamada model omits some important features of FTZs. Hamada model on the establishment of an FTZ lowers the return to capital there. It is unclear why a government seeking to attract foreign investment should adopt policies which have this effect. Furthermore, in this case, foreign investment in the domestic zone (where the return to capital is higher) would have to be barred by the government - whereas the usual FTZ contains a package of benefits which makes it more attractive to foreign investors than the domestic zones.

These paradoxical features of Hamada's model arise from his $2 \times 2$ Heckscher-Ohlin framework. With only one relative commodity price to work with, it is natural to interpret an FTZ as involving the removal of tariff protection on the importable good. Thus, Hamada's model is more applicable to FTZs designed to stimulate consumption such as airport duty-free shops than to many FTZs in developing countries.

He argued that a typical FTZ in LDCs provides a variety of incentives for the purpose of inducing producers to venture into nontraditional export-oriented industries. In order to capture these features of FTZs, FTZ as seen an additional sector. Thus, the formation of an FTZ preserves existing distortions in one relative price in the domestic zone but counteracts them in the FTZ via a distortion in a second relative price. This distortion is favorable to foreign capitalists and hence serves to attract foreign investment in the manner usually associated with an FTZ.

\subsection{Objectives of FTZs}

FTZs are an integral part of an export-oriented development strategy recently adopted by many LDC governments. This emphasis on the export-oriented policies stems from the dismal failures of an earlier development strategy based on import substitution and primary exports. Nowadays, LDC governments desire to emulate those countries which have successfully industrialized their economies through export promotion, most notably, Taiwan, South Korea, Singapore, and Hong Kong. Though the actual policies governing FTZs differ in detail among countries, the basic objectives of FTZs are to enhance foreign exchange earnings, develop export-oriented industries and to generate employment opportunities

For several reasons, non-traditional exports could play an important role in the development and industrialization process in the Third World. For instance, exports may generate the scarce foreign exchange needed to finance imports of industrial inputs and capita1 goods, help to realize economies of scale and also be a source of employment and GNP growth. A common 
policy instrument aimed at stimulating exports has been the establishment of FTZs. The objective is to lure export-oriented enterprises to the FTZs. In addition to free trade status, various incentives such as tax rebates are commonly offered.

Economists over the years have argued that FTZs have a negative or, at best, a very limited positive effect on the host country. Still, FTZs are an increasingly popular trade instrument all over the world, and there are reasons to believe that an important beneficial effect of FTZs. These reasons are broadly classified into bridging object and idea gap.

One common feature of LDCs is infrastructure deficit, as such, the theory of object gap postulates that FTZs would be effective in filling shortage of machinery, human capital, infrastructure, among others.

Another important channel of this catalytic role to economic development is 'bridging idea gaps'. This theory emphasized the role of multinational enterprises and foreign direct investment in diffusing ideas among countries. Many indigenous firms in developing countries lack "export knowhow" that is, the knowledge that would enable them to master the production, marketing, distribution and selling of export goods. Since one purpose of FTZs is to attract foreign direct investment and use foreign knowledge and capita1 to create an export base, local firms may be stimulated to enter the export market by learning from the experience of the foreign affiliates. That is, the foreign affiliates may act catalyst on potential domestic exporters and FTZs may thus contribute to the host country's total exports in two different ways: directly, since the exports from the FTZs is part of the country's total exports but, more importantly, also indirectly by inducing local firms to export.

Ideas include the innumerable insights about packing, marketing, distribution, inventory control, payment systems, information systems, transactions processing, quality control, and worker motivation that all are used in the creation of economic value in a modem economy. Further, this catalyst effect could be more than internal to FTZs, that is, affect not only local firms which operate or are induced to operate within the FTZs, but also spill over to domestic firms outside the FTZs.

Even if both types of gaps coexist in developing countries, and even if overall stable macroeconomic conditions in combination with policy favoring education, secure property rights and legal institutions help to eliminate both of them, the closing of idea gaps requires substantially different policy measures than those for object gaps. In developing countries large gains could be made by exploiting the ideas developed elsewhere and attention is thus directed toward the diffusion of ideas among countries. An important channel for this transmission is foreign direct investment made by multinational enterprises. The foreign affiliates may, for instance, provide an important example for potential indigenous exporters by demonstrating how to combine managerial, technical and marketing know-how in order to enter the world market. That is, the host country may benefit from a catalyst effect stimulating local firms to engage in export activities. A study of individual, nontraditional, manufacturing industries in 11 developing countries and the circumstances behind their successful entry into the world market provides some support for this hypothesis.' The tentative finding is that in almost every case a particular person, firm or public agency played a critical role in the initial export phase by combining local endowments with managerial experience, marketing knowledge and mastery of relevant technology. In industries where the country in question had little or no previous experience, this role was often played by an affiliate of a foreign multinational enterprise. This was especially true for the least developed countries.

Since FTZs are intended to attract foreign multinational enterprises, it is possible that that they could have a catalyst effect on the host country. In the case of Mauritius, for example, the 
Mauritian FTZ played a crucial role in the country's tremendous development record by bringing ideas and knowledge to the island. In a study of the Dominican Republic, it found that the foreign firms present in the zones have initiated exports of a wide range of products and that native managers trained in foreign firms played an important role in the establishment of locally owned firms in the zone. Important vocational training and learning-by-doing was found not only among the officials but also on the factory floor: for example, labor productivity grew rapidly during the first years of a new firm's life reflecting a high degree of on-the-job training of unskilled workers. Thus, foreign firms clearly had a positive impact on the local export supply emanating from the Dominican Republic's FTZs. Other objectives include employment creation, linkages to the host country, foreign exchange earnings and suchlike. It also include capital infrastructure,

\section{Common Mistakes in Establishing FTZs}

A common mistake was to incorporate regional development objectives into the FTZ investment decision. Because of its convenient enclave structure, an FTZ could in principle be located anywhere in the host country and policy makers quickly saw the possibility for killing two birds with one stone. Thus, the FTZs were in some cases established in rural underdeveloped areas considered to be most in need of economic development, in order to promote a more balanced economic development in the country.

Other commonly cited factors explaining the poor performance of several EPZs are poor planning and design, abundance of red-tape procedures, insufficient and inefficient promotion, lack of supporting government policy interventions, and finally, pure mismanagement.

\subsection{Necessary Conditions for Establishing Successful FTZs}

A favorable location, promotion, adherence to the basic FTZ principles, i.e. duty-free imports of inputs, minimized red-tape procedures, guaranteed profit repatriation and the presence of a supporting infrastructure such as telecommunication, electricity, and water.

Since FTZs are most often enclaves, two diametrically opposite scenarios are feasible for initially import-substituting countries. The establishment of an EPZ could either be part of an overall trade-oriented reform program aimed at opening up the country, or regarded as an opportunity to reap the benefits from export promotion while simultaneously continuing with an import-substituting policy in the rest of the country. In the first case, supporting tradeoriented reforms, putting the rest of the country on an equal footing status with the rest of the world, facilitates the spread of the export supply response outside the zone. In Sri Lanka, for example, the introduction of the Katunayake zone was part of a series of trade-oriented reforms. The zone attracted a large number of foreign direct investments. As other types of duty-free regimes were introduced outside the zone, a successful manufacturing export sector evolved, largely located outside the zone. In the latter case, when the import-substituting development policy remains in the rest of the country, the FTZ may well be prosperous per se but the diffusion of the export supply response may be restricted.

An additional important link between the host country's trade policy and FTZs, which indirectly influence the potential for the catalyst to work, is that FTZs might also influence the overall trade policy. Even if the initial intention was to continue with import substitution, a convincing performance of the FTZs may provide both the arguments and the resources needed to induce a policy shift toward greater openness. In China, for example, the developing prosperity within the free economic zones has raised demand for further trade reforms. Such reforms should permit a further expansion of exports. Another possibility, emphasized by the World Bank (1992), is that a successful FTZ may just as easily conserve an inward oriented 
industrial structure in the host country. The underlying reason is that a well-functioning FTZ generates export earnings and creates employment. Since one of the potentially important explanations behind a policy change aimed at reducing anti-export biases is an acute trade deficit due to low export earnings, possibly in combination with high unemployment, the presence of EPZs may prolong the time period in which a country can pursue a protectionist trade strategy, undertaking no or few trade liberalizing reforms. This may be the scenario if the FTZs are important enough to create considerable employment and large inflows of foreign exchange. FTZs accomplishing this are commonly regarded as a successful investment for the host country but if outward orientation is a primary goal, FTZs could delay reforms. This line of reasoning indicates the unsuitability of assessing the performance of FTZs in isolation, not taking the total effect of the FTZ on the host country into account.

Urban and rural areas are compared as appropriate locations for a free-trade zone within a developing country suffering from urban unemployment. If domestic capital is mobile between the two regions, then the rural area is shown to be preferable to the urban area. This conclusion may be reversed, however, if capital is sector-specific.

\section{FTZ: The Nigerian Experience}

\subsection{Overview}

Free Trade Zone is a specifically designated enclave, clearly delineated and administratively considered to be outside the customs Territory of the host country, having special regulatory and fiscal incentive regimes to enhance its competitiveness. It success therefore is anchored on highly efficient infrastructural facilities, less bureaucracy and streamlined One-Stop-Shop operational procedure. The objectives are to fast-track industrialisation and sustainable economic growth.

\subsection{Regulatory Framework for the Establishment of Free Zones}

In Nigeria, there are two types of free trade concept - the specialised and the general-purpose trade/export zone. For effective management of these zones, at the federal level, two bodies are in place - Nigerian Export Processing Zone Authority (NEPZA) for the general-purpose zones and Oil \& Gas Free Zone Authority (OGFZA) for oil \& gas zone.

The licencing, monitoring, regulating and facilitating FTZ is vested in the NEPZA by the EPZ Act 63 of 1992. The act empowers the body to grant all requisite permits and approvals for operators in the zone. The types of FTZs that can be established are public sector, private sector and a combination of both.

\subsubsection{Entry Procedure}

The following are the entry procedures into the zones, for private, public or partnership between private and public:

1. Availability of unnumbered land for the purpose of citing the zone;

2. Obtain and complete prescribed forms from either NEPZA or OGFZA, as applicable; cost of application is not uniform but depends on the tariff Structure of the Zone; on completion of the application form by the prospective investor, it is submitted to the zone of interest; within the framework of NEPZA's operation, the investor is expected to hear of the outcome of the application with 5 working days; and if the application is approved, the enterprise is expected to visit the zone, pay the applicable licencing fees, and become a member of the zone's family. A feasibility report on the projects showing among other things; the Economic and Financial 
Viability; the Socio-Economic Effect of the Project; thorough Evidence of Financial Capability of the Sponsors and a Development plan

3. Submit completed form with the following attachments:

- Project description

- Market survey

- Funding proposal

- Financial projection

- Environmental impact statement and control

4. Procedure for Admitting Companies are as Follows;

5. Upon approval of request, the following steps are thereafter taken:

- company's registration with CAC;

6. If outright purchase of factory building is desired

- $10 \%$ deposit of the selling price of the standard building is made within 3months of approval

- payment of the balance $90 \%, 5$ months after

7. Renting of factory building

- Down payment of one year rent required not exceeding 3months after signing the rental contract. Thereafter, rental charges shall be paid within the first quarter of every year

8. Leasing the standard factory

- Payment of $40 \%$ lease value on approval

- Payment of $30 \%$ at the end of the $5^{\text {th }}$ year

- Payment $\mathrm{f} 30 \%$ balance at the end of the $10^{\text {th }}$ year

9. With condition(s) in (iii) fulfilled, the investor may proceed to carry out the following:

- Remittance of investment capital;

- Importation and installation of machinery; and

- Commencement of production.

\subsection{Types of Industries Permissible in Nigeria Free Trade Zones}

Permissible industries in Nigeria include Electrical and electronic products; Textile products; Wood products; Leather products; Plastics products; Petroleum products; Rubber products; Cosmetics; Garments; Chemicals products; Metal products; Educational materials and equipment; Communication equipment and materials; Sports equipment and materials; Machinery; Handicraft; Optical instruments and appliances; Medical kits and instruments; Biscuits and confectioneries; Printed materials, office equipment and appliances; Paper materials; Food processing; Pharmaceutical products; and Oil \& gas activities.

\subsection{Incentives}

The incentives firms located the zone are expected to enjoy include; exemption from payment of all federal, state and local taxes, levies, rates, and customs duties; repatriation of foreign capital 
investment in EPZs at any time with capital appreciation on the investment; no import or export licence; rent free land during construction of factory space; services such as warehousing, standard pre-built factories, transportation, sanitation, canteen, etc, are available within the zones; unrestricted remittance of profits and dividend earned by investor in the zone; $100 \%$ foreign ownership of enterprises in the EPZ allowable; and enterprise in the zone can sell up to $100 \%$ of their manufactured items, with up to $35 \%$ value addition, in the domestic economy, regardless of whether the item is banned or prohibited.

\subsection{Strategic Evaluation of FTZ}

The first FTZ in Nigeria was established in 1992, which has subsequently increased to 31 as at 2015 , it is apt to evaluate the performance of the zone visa-a-visa the objectives. Specifically, the strategic objectives of the zone are to fast-track industrialization and promote sustainable economic growth. Therefore, robust or unbiased indicators for evaluating the achievement of the strategic objective of the FTZs would effectively focused on the ultimate targets or measurable deliverables. The deliverables consistent with standard literature include increase export, diversify the export-base of the economy, reduce import, improve trade balance, reduce unemployment generation, promote accretion gross external reserves, improve value chain in terms of value added, and increase the number of FDI in Nigeria.

Consistent with the objectives of increasing exports, Figure 1 essentially presents a snapshot of Nigeria's total export from January 1992 to May 2016. Figure 1 show that export was relatively flat from 1992 to 199, maintained an upward trend till 2008 before a sharp fall in 2009, a period that coincided with the global financial crisis.

The same characteristics manifested in July 2014 till date, reflecting the vulnerability of Nigerian export to exogenous shocks. This in essence shows that Nigerian export-base is not diversified and could be driven majorly by oil export. From the behavior of the data, it would be safe to conclude that the objective of increasing export is yet to be achieved. This brings to the fore, the urgent need to rethink the FTZs model adopted in Nigeria.

\section{Figure 1: Crude Oil Prices and Nigeria's Total Export}

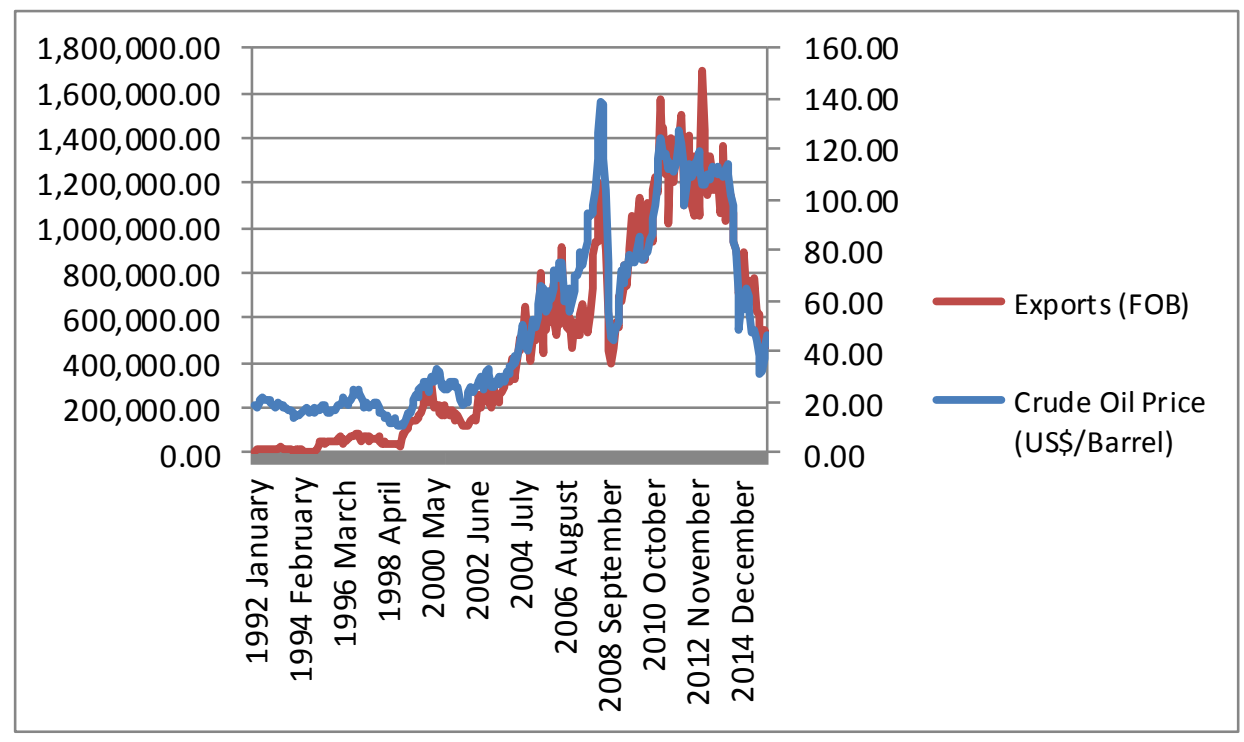

From figure 1 above, Nigeria's export perfectly tracks crude oil prices, which is a strong indicator that the major driver of Nigeria's export is crude oil. Export base that is largely driven by crude oil is a bit tricky. For instance, it has been established in extant literature that foreign 
direct investment in manufacturing industry is more beneficial than foreign direct investment in extractive industry. Scholars attribute this to the number of jobs the manufacturing sector creates, as well as small firms that feed into the value chain of manufacturing industries. Figure 1 clearly shows that crude oil constitute 95 per cent of Nigerian export, which revealed that the objective of diversifying Nigeria's export-base and increase export has not been achieve. Since the law allows enterprises in FTZs to sell at most 35 per cent of their good (value added) in the domestic market, this is expected to reduce import. Again, import data in Figure 2 showed that Nigeria consumption is only susceptible to exogenous shocks. Specifically, Nigeria's import data have been trending upwards from 1991 till date, but with sharp falls in 2007, 2012 and 2015, reflecting period of exogenous shocks. The figure also revealed that the objective of reducing import has not been met.

Figure 2: Nigeria's Import Data (CIF and Total Imports)

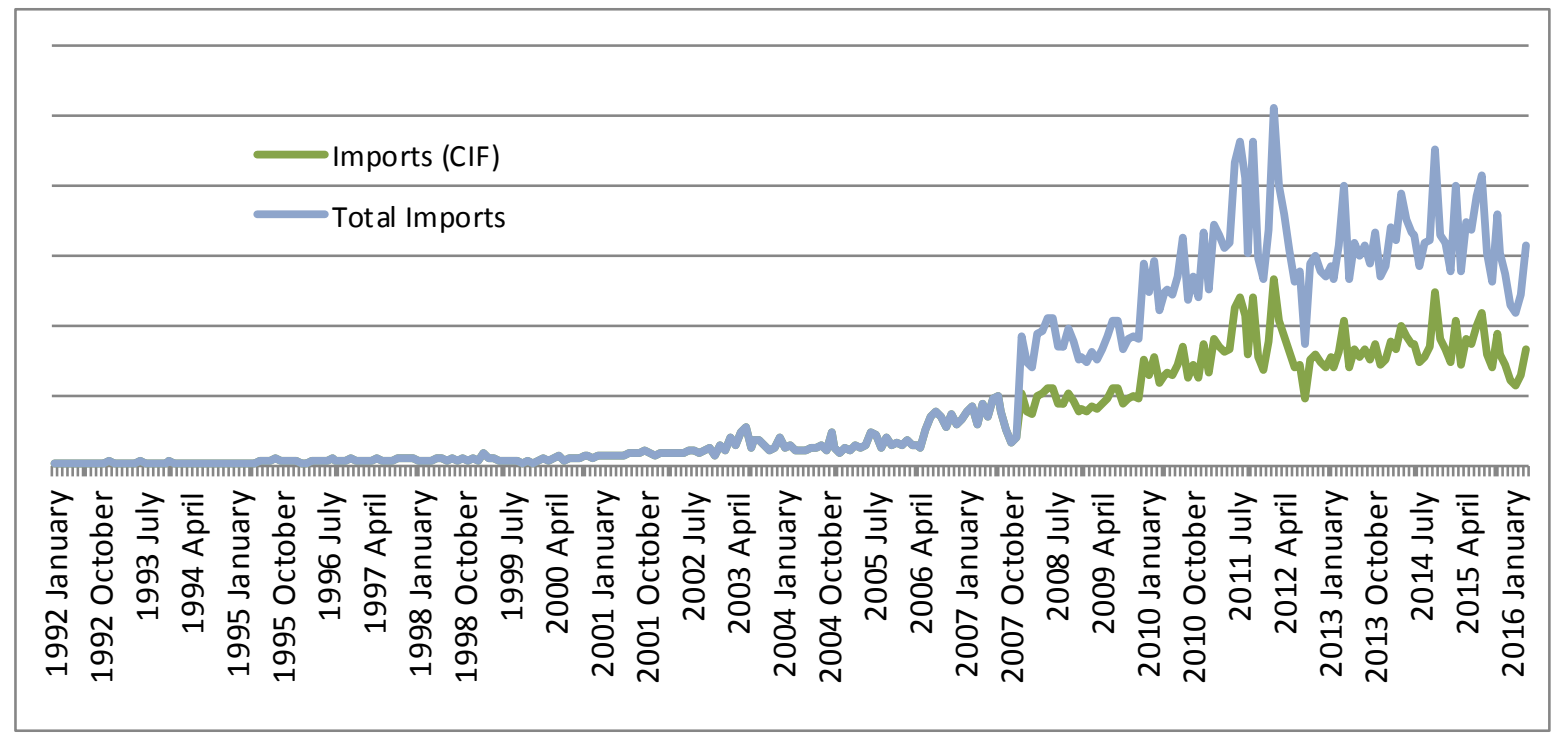

Overall, the cardinal objectives of reducing import, increasing export, and promoting favourable balance of trade has remained elusive, despite the exponential increase in the number of FTZs in Nigeria between 1992 and 2005. For instance, total trade and balance of trade have nose-dived between 2010 and 2016. Figure 3 clearly showed that the performance of Nigeria's balance of trade has not been favourable. Figure 3 illustrates that Nigeria's trade balance is deficit, depicting Nigeria as a net importer and classic consuming nations. This trend tends to negate the overarching objective of establishing FTZs in Nigeria and also brings to the fore, the imperativeness of rethinking the Nigeria's FTZ model, in order to make it operationally effective and in line the development strategy of the government. 
Figure 3: Nigeria's Total Trade and Balance of Trade

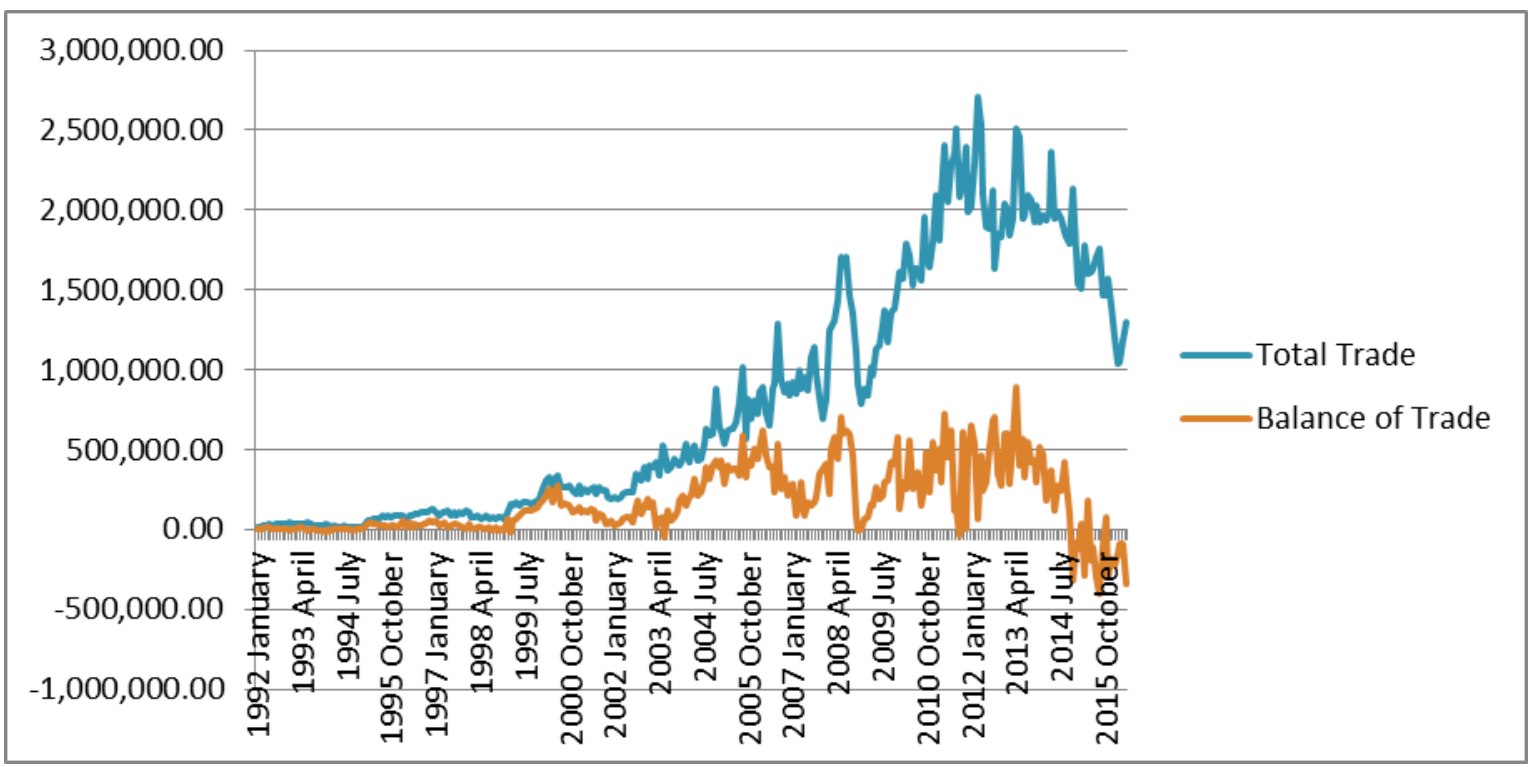

\section{Conclusion and Recommendations}

The review of the performance of FTZs in Nigeria using anecdotal evidence, consistent with the objectives for its establishment, revealed that FTZs in Nigeria have performed sub-optimally. This could be traced to the regulatory framework and business environment. Based on the findings, the study recommends as follows:

i. Need to Promote Inter-Agencies Collaboration among MDAs: The activities of Ministries, Departments and Agency of government appears to conflict in the administration of FTZs in Nigeria. There are cases were state government tax authorities invade the FTZs for the collection of company income tax and personal income tax, which in most cases contradicts the agreements reached between the federal government and foreign companies operating in the zone. There should be extensive collaboration between all tiers of government in the setting up and administration of the zone, in order to avoid interlocking conflicts that may adversely affect the activities of companies in the zone.

ii. Promote Adequate Knowledge of FTZ Scheme: There is an urgent need to extensively increase the knowledge base of government agencies whose functions are organic to the FTZ scheme. Most staff of the zone lack basic ideas of the objectives for establishing the zone, thus, they run the zone like any other agency of the government. They need massive capacity building on their regulatory roles, objectives of the zone, reporting standards, global best practices on the administration of FTZs, among others.

iii. Need to Rethink FTZs as a Location: In most countries, the concept of FTZs has gone beyond setting-up unencumbered land as FTZs. In some jurisdictions, certain hotels are classified as FTZs in order to attract soft skilled manpower to its needed areas. The Nigerian government could start looking in that direction, as this appears to be the best strategy for attracting soft skill experts as private direct investment.

iv. Rethink Power Supply: Epileptic power supply or independent power generation is a common characteristic of most FTZs in Nigeria. The government could rethink this, in terms of setting-up micro-grids. Reputable power generating companies could be 
invited to establish these micro-grids in the zones. This would promote constant power supply, reduce the cost of doing business, and even provide energy source to communities within the zone. More importantly, it would free up energy from the national grid that could be channeled to other potential domestic household users.

v. Lack of Clarity in Government Policies: Some time ago, the government placed some goods on the import prohibition list, the law of FTZs allow the importation of such goods into the zones. Most goods destined for the zones were seized by custom. The lag in resolving the problem resulted in accumulating higher demurrage, and some became bad. Government should strive in providing clarity around its policies.

vi. Need to up-date the laws: FTZs should be reviewed periodically to promote dynamism in regulation.

\section{References}

Bergsten, C.F. (1991), Commentary: The Move Toward Free Trade Zones, Federal Reserve Bank of Kinsas City Economic Review

Hamada, K. (1974), An economic analysis of the duty-free zone, Journal of International Economics 4,225-241.

Hamilton, C. and L.O. Svensson (1982), On the welfare effects of a 'duty-free zone', Journal of International Economics 13,45-64.

Krugman, P. (1991), The Move Towards Free Trade Zones, Federal Reserve Bank of Kinsas City Economic Review

Miyagiwa, K.F. (1986), A Reconstruction of the Welfare Economies of A Free Trade Zone, Journal of International Economics 21, 337-350.

Miyagiwa, K.F. (1993), The locational choice for free-trade zones: Rural versus urban options, Journal of Development Economics 40 (1993) 187-203.

World Bank (1992) Export processing zones, Industry Development Division, Industry Department and Trade Policy Division, Policy and Research Series, The World Bank, Washington, DC. 